\title{
PERKEMBANGAN SOSIAL ANAK USIA DINI SEBAGAI BIBIT UNTUK MASA DEPAN BANGSA
}

\author{
Farida Mayar \\ Dosen Fakultas Ilmu Pendidikan Universitas Negeri Padang \\ e-mail: faridamayar@gmail.com
}

\begin{abstract}
Children social development is determined by the child's individual, the roles of parents, social environment, and Kindegarten. There is a strong relationship between the ability to socialize and the happiness in the childhood. The child's ability to adapt to the environment and the acceptance of environment as well as positive experiences in their social activities serve as crucial factor to reach fun and successful life in the future. Social development is actually a maturity achievement in the social relationship. It can also refer to learning process to adapt to the social norm, moral and tradition: Diffusing into an interrelationship unit to communicate and cooperate. Social development in a family is also influenced by several factors such as status of the family, unity of family, attitudes, and parents' habit.
\end{abstract}

Key words: social development, childhood, future life

\begin{abstract}
Abstrak: Perkembangan sosial anak sangat tergantung pada individu anak, peran orang tua, lingkungan masyarakat dan termasuk Taman Kanak-kanak. Ada kaitan erat antara keterampilan bergaul dengan masa bahagia dimasa kanak-kanak. Kemampuan anak untuk menyessuaikan diri dengan lingkungan. Penerimaan lingkungan serta pengalaman-pengalaman positif lain selama melakukan aktivitas sosial merupakan modal dasar yang sangat penting untuk satu kehidupan sukses dan menyenangkan dimasa yang akan datang, apa anak dipupuk dimasa kanak-kanak akan mereka petik buahnya dimasa dewasa kelak. Perkembangan sosial merupakan pencapaian kematangan dalam hubungan sosial. Dapat juga diartikan sebagai proses belajar untuk menyesuaikan diri terhadap norma kelompok, moral, dan tradisi: Meleburkan diri menjadi suatu kesatuan yang saling berkomunikasi dan bekerjasama. Perkembangan sosial di lingkungan keluarga juga dipengaruhi oleh beberapa faktor, yaitu: Status keluarga, keutuhan keluarga, sikap dan kebiasaan orang tua.
\end{abstract}

Kata Kunci: Perkembangan, sosial, anak masa depan bangsa

\section{PENDAHULUAN}

Perkembangan sosial anak sangat tergantung pada individu anak, peran orang tua, dewasa lingkungan masyarakat dan termasuk Taman Kanak-kanak. Adapun yang dimaksud dengan perkembangan sosial anak adalah bagaimana anak usia dini berinteraksi dengan teman sebaya, orang dewasa dan masyarakat luas agar dapat menyesuaikan diri dengan baik sesuai apa yang diharapkan oleh bangsa dan negara. Ada kaitan erat antara keterampilan bergaul dengan masa bahagia dimasa kanak-kanak. Kemampuan anak untuk menyessuaikan diri dengan lingkungan. Penerimaan lingkungan serta pengalamanpengalaman positif lain selama melakukan aktivitas sosial merupakan modal dasar yang sangat penting untuk satu kehidupan sukses dan menyenangkan dimasa yang akan datang, apa anak dipupuk dimasa kanakkanak akan mereka petik buahnya dimasa dewasa kelak. Namun, kita semua tahu keterampilan bergaul harus dipelajari, dan masa awal kehidupan, anak belajar dari orangorang yang terdekat dengan dalam hal ini, orang tua. Itu sebabnya, selain membimbing dan mengajarkan anak bagaimana cara bergaul dengan tepat, orang tua juga dituntut untuk menjadi model yang baik bagi anaknya. Betapa tidak, anak-anak usia dini yang senang meniru akan meniru apa saja yang dilakukan orang tuanya, termasuk cara bergaul mereka dengan lingkungan. Peran orang tua dalam mengembangkan keterampilan bergaul anak memang benar selain memberi anak kepercayaan dan kesempatan, orang tua juga diharapkan memberi penguatan lewat pemberian rangsangan ganjaran atau hadiah kalau anak bertingkah laku positif atau 
hukuman kalau ia melakukan kesalahan. Dengan begitu anak bisa berkembangan menjadi makhluk sosial yang sehat dan bertanggung jawab. Oleh karena itu, anak yang cerdas, walaupun umurnya 6 tahun, tetapi sudah mampu mengikuti permainan yang membutuhkan strategi berfikir seperti catur. Oleh karena itu, biasanya anak yang cerdas lebih suka bermain dengan anak yang usia lebih tua, sedangkan anak yang kurang cerdas merasa lebih cocok dengan anak lebih muda usianya.

Perkembangan sosial anak bermula dari semenjak bayi, sejalan dengan pertumbuhan badannya, bayi yang telah menjadi anak dan seterusnya menjadi orang dewasa itu, akan mengenal lingkungannya yang lebih luas, mengenai banyak manusia, perkenalan dengan orang lain dimulai dengan mengenal ibunya, kemudian mengenal ayah dan keluarganya. Selanjutnya manusia yang dikenalnya semakin banyak dan amat hitrogen akan bisa munyesuaikan diri untuk masyarakat lebih luas. Akhirnya manusia mengenal kehidu-panan bersama, kemudian bermasyarakat atau bernegara dalam berkehidupan sosial. Dalam perkembangan anak (manusia) akhir-nya mengetahui bahwa manusia itu saling bantu membantu, dan saling memberi dan menerima.

\section{PEMBAHASAN}

Perkembangan merupakan suatu perubahan, dan perubahan ini tidak bersifat kuantitatif, melainkan kualitatif. Perkembangan tidak ditekankan pada segi material. Melainkan pada segi fungsional. Pengertian lain dari perkembangan adalah perubahanperubahan yang dialami oleh individu tau organisme menuju tingkat kedewasaannya atau kematangannya (maturation) yang berlangsung secara sistematis, progresif dana berkesinambungan, baik menyangkut fisik (jasmaniah) maupun psikis (rohaniah). Yusuf (2001:15). Sosial adalah segala perilaku manusia yang menggambarkan hubungan non individuallisme. Sehubungan perkembangan sosial anak ada beberapa aspek esensial yang perlu dipahami dari studi Carsaro (Rizzo, 1990) mengungkapkan bahwa disaat anak berinteraksi dengan kelompok teman sebaya, anak-anak prasekolah saling berbagi (sharing) dalam dua hal. Pertama adalah berupa partisipasi sosial (sosial participation) yakni keterlibatan anak dalam aktivitas bermain bersama atau berupaya mengikuti kegiatan kelompok teman yang sedang berlansung. Kedua adalah berupa perlin-dungan terhadap kawasan pergaulan kelom-pok (the protection of interactive space). Yakni kecenderongan anak yang terlibat dalam suatu episode kegiatan bermain yang sedang berlangsung untuk menolak upaya atau gangguan dari anak lain yang sedang berpatisipasi.

Jadi dapat disimpulkan bahwa perkembangan sosial merupakan pencapaian kematangan dalam hubungan sosial. Dapat juga diartikan sebagai proses belajar untuk menyesuaikan diri terhadap norma, moral, dan tradisi: Meleburkan diri menjadi suatu kesatuan yang saling berkomunikasi dan bekerjasama.

Secara (fitrah) menurut Plato, manusia dilahirkan sebagai makluk sosial (zoon politicon) namun untuk mewujudkan potensi tersebut ia harus berada dalam interkasi dengan lingkungan manusia-manusia lain.

Perkembangan perilaku sosial anak ditandai dengan adanya minat terhadap aktivitas teman-teman dan meningkatkan keinginan yang kuat untuk diterima sebagai anggota suatu kelompok, dan tidak puas bila tidak bersama teman-temannya. Anak tidak lagi puas bermain sendiri di rumah atau dengan saudara-saudara kandung atau melakukan kegiatan dengan anggota-anggota keluarga anak ingin bersamaan temantemannya dan akan merasa kesepian serta tidak puas bila tidak bersama teman-temannya.

Dua atau tiga teman tidaklah cukup baginya. Anak ingin bersama dengan kelompoknya, karena hanya dengan demikian terdapat cukup teman untuk bermain dan berolah raga, dan dapat memberikan kegembiraan. Sejak anak masuk sekolah sampai masa puber, keinginan untuk bersama dan untuk diterima kelompok menjadi semakin 
kuat. Hal ini, berlaku baik untuk anak laki-laki maupun anak perempuan.

\section{A. Ciri-ciri Perkembangan Sosial Anak Usia} Dini Sujiono(2009)

1. Kelahiran sampai Usia Tiga Tahun

a. Bereaksi terhadap orang lain

b. Menikmati pada saat bergaul dengan anak-anak lain

c. Dapat memelihara keterlibatan dengan anak yang lain untuk suatu periode yang sangat pendek

d. Mampu berbagi tanpa perlu membujuk

e. Menunjukkan kemampuan yang sangat kecil untuk menunda kepuasaan.

f. Dapat meniru tindakan dari orang lain

g. Mulai untuk melibatkan diri pada permainan yang parallel.

2. Usia 3-4 tahun

a. Menjadi lebih sadar akan diri sendiri

b. Mengembangkan perasaan rendah hati

c. Menjadi sadar akan rasial dan perbedaan seksual

d. Dapat mengambil arah, mengikuti beberapa aturan

e. Memiliki perasaan yang kuat kea rah rumah dan keluarga

f. Menunjukkan suatu perubahan dalam hal perasaan atau pengertian dari kepercayaan pada diri sendiri.

g. Bermain parallel; mulai bermain permainan yang memerlukan kerja sama. h. Memiliki teman bermain khayalan.

3. Usia 5-6 tahun

a. Menyatakan gagasan yang kaku peran jenis kelamin

b. Memiliki teman baik, meskipun untuk jangka waktu yang pendek

c. Sering bertengkar tetapi dalam waktu yang singkat

d. Dapat berbagi dan mengambil giliran

e. Ikut ambil bagian dalam setiap kegiatan pengalaman di sekolah

f. Mempertimbangkan setiap guru merupakan hal yang sangat penting

g. Ingin menjadi yang nomor satu

h. Menjadi lebih posesif terhadap barang-barang kepunyaannya.

B. Faktor-Faktor yang Mempengaruhi Perkembangan Sosial AUD (Hurlock, 1995)

1. Faktor Lingkungan Keluarga

Untuk mencapai kematangan sosial, anak harus belajar tentang caracara menyesuaikan diri dengan orang lain. Kemampuan ini diperoleh anak melalui kesempatan atau pengalaman bergaul dengan orang-orang dilingkungannya, baik orang tua, saudara, teman sebaya ataupun orang dewasa lainnya. Dan lingkungan keluarga adalah lingkungan yang pertama yang pertama akan dikenal anak.

Perkembangan anak sangat dipengaruhi oleh proses perlakuan atau bimbingan orang tua terhadap anak dalam mengenal berbagai aspek kehidupan sosial, atau norma-norma kehidupan bermasyarakat serta mendorong dan memberikan contoh kepada anaknya bagaimana menerapkan 
norma-norma tersebut dalam kehidupan sehari-hari. Proses bimbingan orang tua ini lazim disebut sosialisasi.

Banyak developmentalis yang bekerja di bidang kebudayaan dan pembanagunan menemukan dirinya sepaham dengan Vygotsky, yang berfokus pada konteks pembangunanan sosial budaya. Mengatakan manusia sebagai sesuatu yang tidak terpisahkan dari kegiatan-kegiatan sosial dan budaya. Dan juga menekankan anak berkembang sosialnya dibantu, dibimbing oleh oleh orang yang terampil dalam bidang sosial tersebut (Ayuningsih, 2010)

Perkembangan sosial di lingkungan keluarga juga dipengaruhi oleh beberapa faktor, yaitu:

\section{a. Status di Keluarga}

Sosialisasi seorang anak akan dipengaruhi oleh statusnya. Siapakah ia di dalam keluarga tersebut? Apakah seorang kakak, adek, anak dan lainnya. Hal ini akan mempengaruhi proses sosialisasinya, seperti bagaimana ia harus berperan ketika menjadi anak, ketika menjadi adek, dan ketika kakak.

\section{b. Keutuhan Keluarga}

Jika sebuah keluarga yang keutuhannya bagus, jarang terdengar konflik di dalamnya, maka sosialisasi anak dapat berjalan dengan lancer, karena tidak ada faktor yang mengganggu berjalan proses sosialisasi anak tersebut.

\section{c. Sikap dan Kebiasaan Orang tua}

Sikap dan kebiasaan orang tua akan menurun juga kepada anaknya. Jika orang tua yang mempunyai sikap ramah dan memiliki hubungan yang baik dengan orang-orang sekitar, maka dapat dipastikan sosial anak juga akan bagus.

\section{Faktor Dari Luar Rumah}

Faktor di luar rumah adalah wadah bagi anak untuk bersosialisasi. Di luar rumah anak akan bertemu dengan orang yang lebih banyak, seperti teman sebaya, orang yang lebih kecil darinya, orang dewasa, sehinggga sosialnya akan berjalan sesuai dengan perannya di lingkungan tersebut.

3. Faktor Pengaruh Pengalaman Sosial Anak

Jika seorang anak memiliki pengalaman sosial yang buruk, seperti tidak diperbolehkan main keluar rumah oleh orang tuanya, maka hal itu, akan berpengaruh bagi proses sosialisasinya kepada lingkungan sekitarnya yang berada di luar rumah. Hal ini, akan menyebabkan anak menjadi tidak tahu dan kurang bersosialisasi dengan lingkungan di luar rumah.

Dalam pembelajaran anak melalui interaksi sosial baik dengan orang dewasa maupun dengan teman sebaya yang ada dilingkungan nya. Salah satu cara anak belajar adalah dengan cara mengamati, meniru, dan melakukan. Orang dewasa dan teman-teman yang dekat dengan kehidupan anak merupakan objek yang diamati dan ditiru anak. Muhammad, (2011). Melalui cara ini anak belajar cara bersikap, berkomunilasi, berempati, menghargai atau pengetahuan dan keterampilan lainnya. Pendidikan dan orang-orang dewasa di sekitar anak seharusnya peka dan menyadari bahwa dirinya sebagai model yang pantas untuk ditiru anak dalam berucap, bersikap, merespon anak dan orang lain, sehingga dapat membantu 
anak mengembangkan kemampuan berkomunikasi dan kematangan emosinya. Disisi lain anak belajar sesuai dengan kondisi sosial budayanya. Tumbuh dan berkembang sesuai dengan berdasarkan pada sosial budaya yang berlaku di lingkungan. Pendidik seharusnya mengenal budaya, kesenian, dolanan anak, baju daerah menjadi bagian setting dan pembelajaran baik secara regular maupun melalui kegiatan tertentu sehingga anak biasa mempersiapkan bibit sosial dimasa depannya.

C. Usaha Guru untuk Mengembangkan Sosial AUD

Beberapa hal berikut ini merupakan sedikit usul dari beberapa cara yang ada untuk mempromosikan mengenai adanya suatu pertumbuhan di dalam kemampuan sosial, yaitu:

1. Menyediakan sudut berhias dimana anak-anak dapat bebrdanan dan untuk memainkan berbagai peran. Seragam yang sederhana seperti celemek dan topi dapat membantu anak-anak untuk menyelidiki tentang peran yang baru. Tiga dan empat kebutuhan yang lain memerlukanbantuan dari keluarg; anak-anak yang lebih tua memerlukan penyangga yang lebih baik untuk memerankan peranan yang lebih besar yang ada di dalam masyarakat

2. Bagi anak-anak yang berusia tiga tahun, alat-alat permainan yang baik harus mencukupi lebih lama lagi untuk mengikuti putaran kegiatan yang berikutnya. Ketika anak-anak beranjak dewasa, para guru boleh membantu anak-anak memeilih salah satu pendekatan ketika mereka sedang menunggu gliran dan berbagi mainan dan peralatan seperti misalnya pengunaan system menunggu, mengu- nakan suatu pengatur waktu, dan seterusnya

3. Mengunakan suatu untuk model teknik yang sesuai dalam memasuki suatu kelompok bermain, sebagai contoh, guru dapat mengunakan sebuah boneka untuk menunjukan bagaimana seorang anak akan bertanya pada sekolompok bermain anak yang sedang bermain apakah dan dapat ikut serta bermain di dalam kelompok tersebut, tentu saja apabila diperolehkan oleh kelompok tersebut.

4. Mendorong anak-anak untuk membuat keputusan sebayak mungkin . dalam bermain bebas, izinkan anak untuk memilih dan melakukan sesuatu. Dalam kegiatan di suatu hari, seperti musik, atau bercerita, dorong juga anak untuk memilih salah satu lagu atau cerita.

5. Model empati dan mempeduli perilaku serta mendorong anak-anak untuk melakukan perilaku ini.

6. Bermain peran merupakan solusi untuk memecahkan masalah dalam interaksi sosial. Sebagai contoh, anakanak mungkin akan memainkan peranan tentang bagaimana cara membuat suatu pengenalan ketika seseorang tamu datang ke dalam kelas atau bagaimana cara untuk meminta anak lan untuk berbagai bahan-bahan.

\section{SIMPULAN}

Perkembangan sosial merupakan pencapaian kematangan dalam hubungan sosial. Dapat juga diartikan sebagai proses belajar untuk menyesuaikan diri terhadap norma-nrma kelompok, moral, dan tradisi; meleburkn diri menjadi suatu kesatuan yang saling berkmunikasi dan berkerja sama dengan orang banyak. Sehingga anak menjadi anak ekstropet anak yang ramah dalam 
bersosialisasi dimana anak untuk mengambil keputusan atas kebersamaan kesepakatan bersama inilah yang diharapkan oleh bangsa dan Negara. Disisi lain anak intropet artinya anak tidak mau bersoaialisasi dan mengambil keputusan atas dirinya tanpa memperhatian teman yang lain. Oleh karena itu, kita sebagai pendidik anak usia dini seyognya membimbing, membina dan melatih anak bersosialisasi untuk menjadi orang yang matang bersosial kelak dewasa menjadi keadilan sosial di masyarakat sesuai dengan sila kelima dari Pancasila.

Ciri-ciri perkembangan sosial AUD sebagai berikut: kelahiran sampai usia tiga tahun bereaksi terhadap orang lain, usia 3-4 tahun; menjadi lebih sadar akan diri sendiri, usia 5-6 tahun; menyatakan gagasan yang kaku tentang peran jenis kelamin. Usia 78tahun; lebih sering bersaing dengan teman sebaya.

Faktor-faktor yang mempengaruhi perkembangan sosial AUD: faktor ling-kungan keluarga: status di keluarga, keutuhan keluarga, sikap dan kebiasaan orangtua; faktor dari luar rumah; faktor pengaruh pengalaman sosial anak.

Usaha guru untuk mengembangkan sosial AUD: menyediakan sudut berhias; bagi anak-anak yang berusia 3 tahun, alat-alat permainan yang baik harus mencukupi; menggunakan boneka untuk model teknik yang sesuai dalam memasuki suatu kelompok bermain; mendorong anak-anak untuk membuat keputusan sebanyak mungkin; model empati dan mempedulikan perilaku serta mendorong anak-anak untuk melakukan perilaku ini; bermain peran merupakan solusi untuk memecahkan masalah dalam interaksi sosial.

\section{DAFTAR RUJUKAN}

Ayuningsih, Diah. 2010. Psikologi Perkembangan Anak. Yogyakarta: Pustaka Larasati http://piaud4ppssts.blogspot.com/2012/04/pera n-bermain-bagi-perkembangansosial.html

http://kongkoh.blogspot.com/2011/01/perkemb angan-sosial-dan-emosional-anak.html
Hurlock, Elizabet B. Perkembangan Perkembangan Anak Jilid I, edisi keenam. Jakarta: Erlangga.

Muhammad, Hamid. 2011. Petunjuk Teknis penyelengaraan Taman kanak-kanak. Jakarta: Kemendiknas 
Rizzo. 1990. Friendsip Developmen Among Cildren in Scool. Norwood, New Jersey: Ablex Publishing Corporation.

Sujiono Yuliani Nurani. 2009. Konsep Dasar Pendidikan Anak Usia Dini. Jakarta: PT Indeks 